\title{
Evidences of Polymorphism Associated with Circadian System and Risk of Pathologies: A Review of the Literature
}

\author{
F. J. Valenzuela, ${ }^{1,2}$ J. Vera, ${ }^{1,2}$ C. Venegas, ${ }^{1}$ S. Muñoz, ${ }^{1}$ S. Oyarce, \\ K. Muñoz, ${ }^{1}$ and C. Lagunas ${ }^{1}$ \\ ${ }^{1}$ Department of Basic Sciences, Universidad del Bío-Bío, Campus Fernando May, 378000 Chillán, Chile \\ ${ }^{2}$ Group of Biotechnological Sciences, Department of Basic Sciences, Universidad del Bío-Bío, Campus Fernando May, \\ 378000 Chillán, Chile
}

Correspondence should be addressed to F. J. Valenzuela; fvalenzuela@ubiobio.cl

Received 22 January 2016; Revised 14 April 2016; Accepted 19 April 2016

Academic Editor: Darío A. Castroviejo

Copyright (C) 2016 F. J. Valenzuela et al. This is an open access article distributed under the Creative Commons Attribution License, which permits unrestricted use, distribution, and reproduction in any medium, provided the original work is properly cited.

\begin{abstract}
The circadian system is a supraphysiological system that modulates different biological functions such as metabolism, sleepwake, cellular proliferation, and body temperature. Different chronodisruptors have been identified, such as shift work, feeding time, long days, and stress. The environmental changes and our modern lifestyle can alter the circadian system and increase the risk of developing pathologies such as cancer, preeclampsia, diabetes, and mood disorder. This system is organized by transcriptional/tranductional feedback loops of clock genes Clock, Bmal1, Per1-3, and Cry1-2. How molecular components of the clock are able to influence the development of diseases and their risk relation with genetic components of polymorphism of clock genes is unknown. This research describes different genetic variations in the population and how these are associated with risk of cancer, metabolic diseases such as diabetes, obesity, and dyslipidemias, and also mood disorders such as depression, bipolar disease, excessive alcohol intake, and infertility. Finally, these findings will need to be implemented and evaluated at the level of genetic interaction and how the environment factors trigger the expression of these pathologies will be examined.
\end{abstract}

\section{Introduction}

The circadian system organizes the different biological functions in $24 \mathrm{~h}$, such as sleep/activity, temperature [1], heart rate, glucose level, cortisol production [2], and oxidative stress [3]. In mammals, this system is organized by a central clock localized in the suprachiasmatic nucleus of the hypothalamus (SCN) and in a series of peripheral oscillators such as the liver, lung, adrenal gland, fibroblast cells, and others tissues $[2,4]$. The peripheral oscillators are synchronized every day via nervous or humoral signals, and the most important humoral signal is the melatonin hormone, secreted by the pineal gland during the dark hours, and its impairment is associated with different disorders such as insomnia, cardiovascular disease, and cancer [5].

The molecular clock is organized by transcriptional/translational feedback loop of clock genes named Clock, Bmall, Per1-3, and Cry1-2. At the molecular level, the complex
Clock-Bmall stimulates the expression of negative regulators Per1-3 and Cry1-2, and their protein inhibits the effect of the heterodimer Clock/Bmall [6, 7]. Moreover, the molecular clock has different modulators which give fine tuning of output signals such as Rev-erb $\alpha$, a negative regulator of BMAL1 expression [7-9], SIRT1, a regulator of Clock-mediated acetylase activity $[10,11]$, and PGCl $\alpha$, a stimulator of Bmal1 expression [12, 13] (see Figure 1). This system provides an output signal to genes such as Hexokinase [14], DBP [1517], VEGF [18], steroidogenic enzymes StAR, $3 \beta$-HSD [19], and Wee-1 [20], giving a circadian oscillation of physiological functions such as metabolism [14], angiogenesis [18], cortisol production $[2,19]$, and cellular proliferation [20].

The molecular clock can be modified by environmental changes and our modern lifestyle, resulting in physiological alteration and risk of pathologies; for example, during the monkey's pregnancy, the light exposition during night hours induces a lower body temperature and absence of circadian 


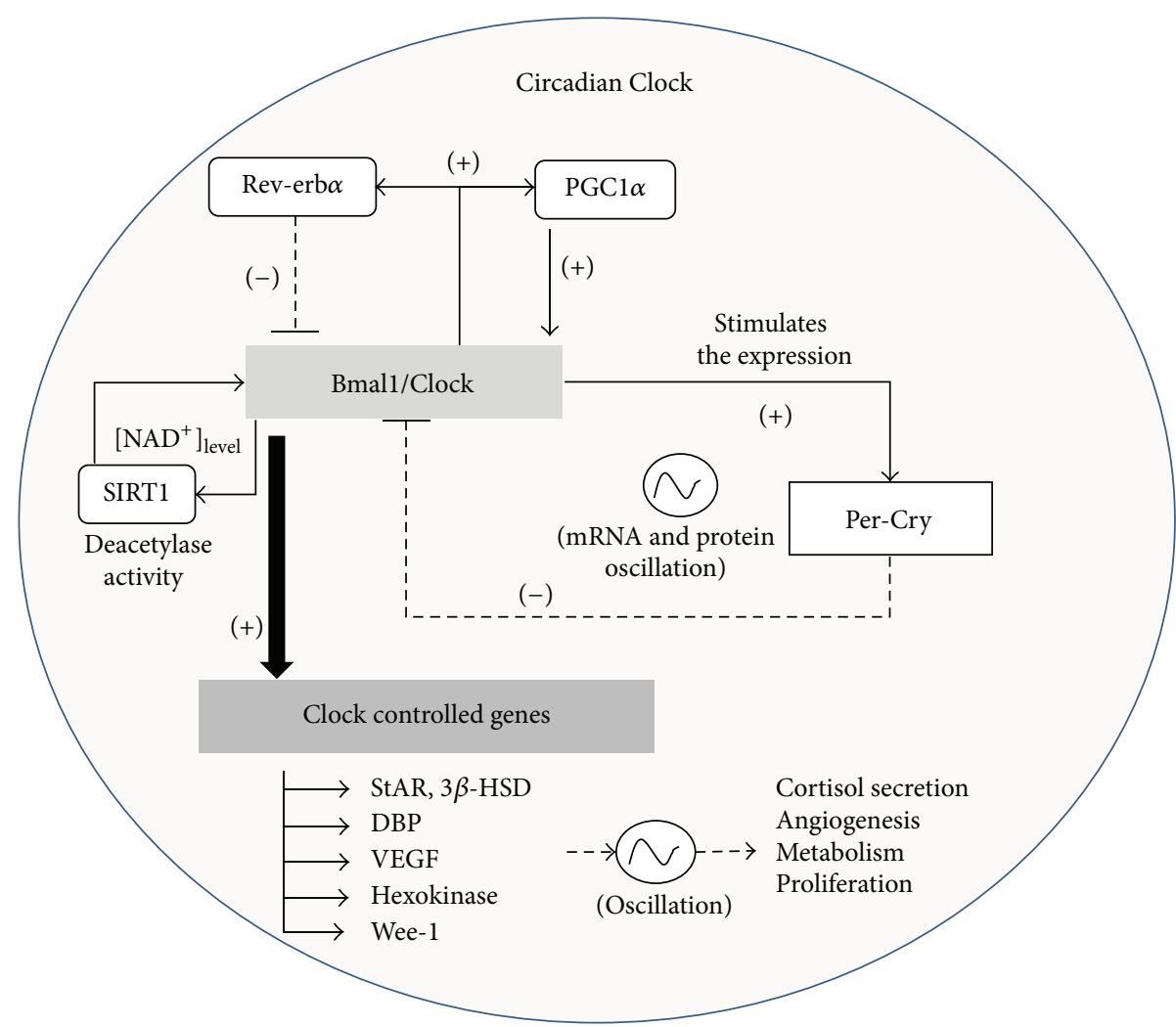

Figure 1: Circadian Clock. Positive regulation of clock genes Bmal1 and Clock stimulates promoter of negative regulators Per1-3, Cry 1-2, and controlled clock genes StAR, $3 \beta$-HSD, DBP, VEGF, Hexokinase, and Wee-1. Moreover, the molecular clock regulates the deacetylase activity of SIRT1 by regulation of $\mathrm{NAD}^{+} / \mathrm{NADH}$ ratio.

rhythm of temperature in the newborn [1]. In humans, different reports showed that the alterations of the circadian system increased the risks of cancer [21-23], preeclampsia [24], diabetes [3, 25], and mood disorder [26]. Curiously, a large quantity of polymorphisms has been detected in clock genes, which can be influencing the development of diseases through different physiological systems. This review will primarily focus on the hypothesis which states that the variation of genetic components of the circadian system, similar to environmental changes, can affect several physiological systems and produce an elevation of the risk of developing a disease.

In recent years, there has been a significant increase in available information from polymorphic variations and epigenetic modification over clock genes and their risk of diseases.

The report of health from the United States (2014) showed about $10 \%$ of population have a poor health associated with pathologies such as obesity (35.5\%), hypercholesterolemia (30\%), diabetes (32\%), and cancer (6.4\%) [27]. Curiously, despite its low frequency in population, cancer is the second cause of death in the United States [27]. The above pathologies add the infertility, which affects about $10.9 \%$ of women in the United States [27] and 17\% of women in other developed countries [28]. During short-stay in the hospital, mood disorder and psychosis are the principal causer of hospital stay during 2014 and represent the third cause of morbidity worldwide [29]. This present research reports the last single nucleotide polymorphism (SNP) associated with an elevated risk of developing principal pathologies worldwide such as mood disorder [30], infertility [31], cancer [32], metabolism and diabetes [33] and addictions [34], and a description of usefulness for a more detailed study in other pathologies.

\section{Clock Genes and Metabolic Disorder}

In mammals, the circadian system is a supraphysiological system that regulates biological functions every $24 \mathrm{~h}$ [35] such as glucose homeostasis [36], temperature [1], blood pressure, tone in the coronary artery, and heart rate [37]. The Bmall/Clock complex target genes are related to the circadian expression of metabolic pathways as was observed by Hatanaka et al. [38] through high resolution genome-wide mapping in the liver of mice. The author detected a circadian expression of (I) glucose metabolism-related genes such as Glut2, Por, Pckl, and Gys2 and (II) cholesterol metabolismrelated genes such as Cyp2a4, Cyp2a5, Cyp4a14, Cyp7a1, and Cyp2c55 [38]; and considering the very important role these systems have in metabolism, any alteration of them can have negative health effects.

Today there are several metabolic problems affecting the population, such as obesity, hyperglycemia, dyslipidemia, and hypertension [39]. The cooccurrence of three or more metabolic disorders, including obesity, is defined as "metabolic syndrome" [39], showing a prevalence in the United States 
during 2009-2010 of about $22 \%$ of adults (21.46-26.15) [40]. The insulin resistance or type 2 diabetes is one of the most important metabolic diseases currently affecting about 366 million people [41], causing more than 3.8 million deaths [42], and showing a rise in the number of affected people as observed in the United States population during 19992010 [40]. Several factors could be increasing the risk of death by diabetes, such as dyslipidemia, hypertension, and obesity [43], all of which are driving to an elevated risk of cardiovascular disease. A variant of this pathology can also develop during the pregnancy (gestational diabetes mellitus) and is characterized by glucose intolerance [44] in the mother and adverse consequences for her offspring, such as an increase in blood pressure, body mass index (BMI), and body fat and a decrease in HDL levels [43]. At the molecular level, both diseases have in common the impairment of signal transduction of insulin receptors such as PI3Kinase/Akt and Ras/MAP kinases [42, 45, 46], leading to metabolic dysregulations [42] such as inhibitions of glycogen synthesis, impaired translocation of Glut 4 to plasmatic membrane, or antilipolytic effects of insulin in white adipose tissue $[39,46]$.

Meta-analyses from 448 articles reporting shift work and health consequence have detected a strong relationship between shift work, a potent chronodisruptor, and diabetes mellitus type 2 (odd ratio about 1.42 times higher than day workers) [47]. However, this is not the only chronodisruption which we are exposed too. In animal models exposed to light/dark patterns similar to shift work, the length of the working day and changes of feeding times induce a modification of the liver weight and plasmatic glucose and a modification of the circadian profile for glucose, insulin, and triglyceride [48]. These findings add to the observation in the circadian disruption in mutant animals, showing alterations of cholesterol metabolism, abolition of the circadian production of glycerol, free fatty acids, and impaired expression of rate-limiting lipolytic enzymes such as lipase [49], all of which add to increased weight gain, adipocyte hypertrophy [49], high level of glucose, glucose intolerance, and hypersecretion of insulin [49-52]. Polymorphic variations of clock genes can be incrementing the risks of developing a disease similar to chronodisruption by environmental changes as it has been detected in human metabolic disorders (see Table 1). For example, the genotyping of clock genes in 346 Greek pregnant women and their risk of diabetes was performed, detecting that the polymorphisms of Bmal1 rs7950226 and rs11022775 are associated with gestational diabetes mellitus $(P=0.025, \mathrm{OR}=1.46$ and $P=4.455 e-06, \mathrm{OR}=$ 2.64 , resp.), while the study of the haplotype analysis of rs7950226/rs11022775 showed a major frequency in women with gestational diabetes mellitus $(P=0.0069$, $\mathrm{OR}=6.96)$ [33]. Similarly, a study performed in subjects from the United Kingdom and Pakistan reported that Cry1 and Cry 2 polymorphisms rs2292912 and rs12315175, respectively, are associated with diabetes $(P=0.015$ and 0.008 , resp.). Moreover, the variant $r s 12315175$ for $C r y 2$ has a tendency to elevate the risk at about $5 \%$ compared to the variation of $\mathrm{Cryl}(\mathrm{OR}=1.05$ and 0.95, resp.) [53]. Also, the authors did not find associations between diabetes and Bmall polymorphisms rs7950226 and rs11022775 [53], as occurs in gestational diabetes mellitus
[33]. Genotyping of 19,000 adults from Northern Sweden for variants rs8192440 for Cryl and rs11605924 for Cry2 is associated with higher level of glucose concentrations at 2 hours ( $P=0.06$ and $P=0.005$, resp.) [54].

Another study genotyping 1304 individuals from 424 British families, containing at least one patient with diabetes type 2 (diabetes in families study collection), demonstrates the relation between Bmal1 polymorphisms $r s 7950226$ and rs11022775 and diabetes $(P=0.002)$, reinforcing what was previously described [55]. Similar relations are observed for Bmal2 polymorphism rs7958822 in obese men and women (OR 2.2 and 2.7, resp.) [56] and the deletion/insertion of 54 base pair sequences of five repeat alleles on Per3 gene ( $r$ 57875989) [57, 58]. In contrast, the Per2 polymorphism rs 7602358 is associated with a protection from type 2 diabetes in the UK population, which suggests that not all polymorphisms are negative for health [53].

At the level of dyslipidemia, an interesting correlation has been detected between small dense LDL level and polymorphism of clock genes. In individuals carrying the polymorphism associated with the Clock gene (rs1801260), the genotype TT or TC showed a major level of small dense LDL, which leads to increased triglycerides and increased risk of cardiovascular and obesity diseases [59], similar to the "metabolic syndrome" [39]. Likewise, genotyping in the Japanese population identified Clock gene polymorphism rs1801260 associated with higher odds ratio (OR; 1.5) of type 2 diabetes [60]; in contrast, a multicenter study detected the Clock polymorphism rs4580704 is associated with prevention of diabetes and cardiovascular disease [61]. The haplotypes of rs10002541 and rs4864546 from Clock (CG and TG variations) are associated with abdominal obesity in Chinese population (OR 0.74 and 1.70, resp.) [62] and polymorphism rs4864546 is associated with low level of HDL/apolipoprotein A1 ratio in Spain [63]. Moreover, Clock polymorphisms rs12649507 and rs3749474 are associated with higher intake of polyunsaturated fatty acid [64] and fat intake [65], which can modify the body mass index (BMI). This is an antecedent which, bearing in mind the ideas above, suggests the genetic components of the circadian system as a critical factor in the development of metabolic diseases.

\section{Clock Genes and Infertility}

In humans, infertility affects about $9 \%$ of couples, and about one-third of infertility cases associated with idiopathic male infertility are multifactorial, with $50 \%$ due to genetic abnormalities [88]. The circadian system is important during reproduction and development $[89,90]$; for example, it is involved in the timing of the LH surge $[90,91]$, stimulation of ovulation $[90,92]$, and regulating the level of steroidogenic acute regulatory protein (StAR) expression and is critical for cholesterol translocation inside mitochondria and sperm count [93].

The genetic factors of clock genes are implicated in the pathogenesis of infertility (see Table 2), as it occurs in male partners of infertile couples. The genotyping of male partners detected a correlation between single nucleotide polymorphism of Clock rs11932595, rs6811520, and 6850524, 
TABLE 1: Polymorphisms of clock genes associated with metabolic disorders.

\begin{tabular}{|c|c|c|c|c|c|}
\hline Gene & SNPs & Variation & Localization & Pathology & Reference \\
\hline \multirow{6}{*}{ Clock } & rs 1801260 & $\mathrm{~T}>\mathrm{C}$ & $\begin{array}{c}\text { Chromosome } 4 ; 3^{\prime} \text { UTR; Homo } \\
\text { sapiens }\end{array}$ & $\begin{array}{l}\text { Dyslipidemia and } \\
\text { diabetes }\end{array}$ & {$[59,60]$} \\
\hline & rs10002541 & $\mathrm{T}>\mathrm{C}$ & $\begin{array}{l}\text { Chromosome } 4 \text {; intron; Homo } \\
\text { sapiens }\end{array}$ & Diabetes & {$[62]$} \\
\hline & rs12649507 & $\mathrm{G}>\mathrm{A}$ & $\begin{array}{l}\text { Chromosome } 4 \text {; intron; Homo } \\
\text { sapiens }\end{array}$ & Food intake & {$[64]$} \\
\hline & rs4580704 & $\mathrm{G}>\mathrm{C}$ & $\begin{array}{l}\text { Chromosome } 4 \text {; intron; Homo } \\
\text { sapiens }\end{array}$ & $\begin{array}{c}\text { Diabetes, } \\
\text { cardiovascular } \\
\text { disease, and HDL } \\
\text { level }\end{array}$ & {$[61,63]$} \\
\hline & rs3749474 & $\mathrm{C}>\mathrm{T}$ & $\begin{array}{c}\text { Chromosome } 4 \text {; 3-UTR; Homo } \\
\text { sapiens }\end{array}$ & Food intake & {$[65]$} \\
\hline & $r s 4864546$ & $\mathrm{G}>\mathrm{A}$ & $\begin{array}{c}\text { Chromosome 4; near gene- } 5^{\prime} \text {; } \\
\text { Homo sapiens. }\end{array}$ & Diabetes & {$[62]$} \\
\hline Per2 & rs7602358 & $\mathrm{G}>\mathrm{T}$ & $\begin{array}{l}\text { Chromosome } 2 \text {; intron; Homo } \\
\text { sapiens }\end{array}$ & Diabetes & {$[32]$} \\
\hline Per3 & rs57875989 & Deletion/insertion & $\begin{array}{c}\text { Chromosome } 1 ; 5^{\prime} \text { near gene; } \\
\text { Homo sapiens }\end{array}$ & Diabetes & {$[57,58]$} \\
\hline \multirow{2}{*}{ Bmal1 } & rs11022775 & $\mathrm{C}>\mathrm{T}$ & $\begin{array}{l}\text { Chromosome 11; intron; Homo } \\
\text { sapiens }\end{array}$ & $\begin{array}{l}\text { Gestational diabetes } \\
\text { mellitus }\end{array}$ & [33] \\
\hline & rs7950226 & $\mathrm{G}>\mathrm{A}$ & $\begin{array}{l}\text { Chromosome } 11 \text {; intron; Homo } \\
\text { sapiens }\end{array}$ & $\begin{array}{l}\text { Gestational diabetes } \\
\text { mellitus }\end{array}$ & [33] \\
\hline Bmal2 & rs7958822 & $\mathrm{G}>\mathrm{A}$ & $\begin{array}{l}\text { Chromosome } 12 \text {; intron; Homo } \\
\text { sapiens }\end{array}$ & Diabetes & {$[56]$} \\
\hline \multirow[b]{2}{*}{ Cryl } & $r s 12315175$ & $\mathrm{~T}>\mathrm{C}$ & Chromosome 12; Homo sapiens & Diabetes & {$[53]$} \\
\hline & rs8192440 & $A>G$ & $\begin{array}{l}\text { Chromosome 12; CDS; Homo } \\
\text { sapiens }\end{array}$ & Diabetes & {$[54]$} \\
\hline \multirow{2}{*}{ Cry 2} & rs11605924 & $\mathrm{A}>\mathrm{C}$ & $\begin{array}{l}\text { Chromosome 11; intron; Homo } \\
\text { sapiens }\end{array}$ & Diabetes & {$[54]$} \\
\hline & rs2292912 & $\mathrm{C}>\mathrm{G} / \mathrm{T}$ & $\begin{array}{l}\text { Chromosome } 11 \text {; intron; Homo } \\
\text { sapiens }\end{array}$ & Diabetes & {$[53]$} \\
\hline
\end{tabular}

with infertility $(P<0.05$ and OR ranged between 1.4 and 1.9). Similarly, the analysis of Bmall polymorphism $r$ s457144 in Slovenian and Serbian Caucasian men showed a significant correlation with infertility $(P=0.047)$ [31], suggesting that clock genes Clock and Bmall contribute to successful fertilization.

\section{Clock Genes, Mood Disorder, and Others}

Mood or affective disorders are important causes of morbidity, where we can highlight depressive pathologies and hypomaniac and maniac disorders as major diseases affecting the population $[29,66]$, and it can be highlighted that depressive pathologies are the third largest source of morbidity in the world [29]. Curiously, a potent correlation has been detected between mood disorders, sleep/activity, and the circadian system [94] suggesting that the circadian system can be modulating the neuronal activity [95]. During pregnancy, the prevalence of mental illnesses in women is about $8 \%$ [96], suggesting an imbalance between physiology of sleep and/or the circadian system. This can be observed in the onset of a mental disease as has been observed in the impaired circadian production of melatonin during the pregnancy of depressed women (approximately $\leq 34$ weeks of gestation), which shows an advance onset time of melatonin production of about 40 minutes and a minor production during the dark hours [97, 98]. Moreover, workers who do shift work (circadian disruption) showed decreased alertness, cognitive functions, mood, social and work activities, and health $[26,99]$, which are associated with an impaired circadian system via melatonin suppression, all of which leads to the appearance of a mood disorder [99]. For this reason, we can say that the circadian system may contribute to the risk of developing a mood disorder and the genetic component of clock genes can be involved in the development of mood pathologies [94] (see Table 2).

At the genetic component level of the circadian system, a study of 744 people who carry polymorphisms rs2291739 and rs11171856 from TIM, a member of the clock gene family which interacts with Perl-2 proteins $[100,101]$, showed that they have an elevated risk of developing mood disorders ranging between 19 and 23\% (OR 1.19 and 1.23, resp.) [66]. Moreover, gene variants of positive regulator Clock have also been associated with mood disorders. People who carry the 
TABLE 2: Polymorphisms of clock genes associated with infertility and mood disorders.

\begin{tabular}{|c|c|c|c|c|c|}
\hline Gene & SNPs & Variation & Localization & Pathology & Reference \\
\hline \multirow{4}{*}{ Clock } & rs1801260 & $\mathrm{T}>\mathrm{C}$ & $\begin{array}{c}\text { Chromosome } 4 ; 3^{\prime} \text { UTR; Homo } \\
\text { sapiens }\end{array}$ & Bipolar disease & {$[66]$} \\
\hline & rs11932595 & $A>G$ & $\begin{array}{l}\text { Chromosome } 4 \text {; intron; Homo } \\
\text { sapiens }\end{array}$ & Infertility and bipolar disease & {$[31,66]$} \\
\hline & rs6811520 & $\mathrm{T}>\mathrm{C}$ & $\begin{array}{c}\text { Chromosome } 4 \text {; intron; Homo } \\
\text { sapiens }\end{array}$ & Infertility & {$[31]$} \\
\hline & rs6850524 & $\mathrm{G}>\mathrm{C}$ & $\begin{array}{l}\text { Chromosome } 4 \text {; intron; Homo } \\
\text { sapiens }\end{array}$ & Infertility & {$[31]$} \\
\hline Per2 & $r s 56013859$ & $\mathrm{~T}>\mathrm{C}$ & $\begin{array}{l}\text { Chromosome 2; intron; Homo } \\
\text { sapiens }\end{array}$ & Alcohol intake & {$[34]$} \\
\hline \multirow{2}{*}{ Per3 } & rs57875989 & Deletion/insertion & $\begin{array}{c}\text { Chromosome } 1 ; 5^{\prime} \text { near gene; } \\
\text { Homo sapiens }\end{array}$ & Bipolar disease & {$[67,68]$} \\
\hline & rs 2859387 & $\mathrm{G}>\mathrm{A} / \mathrm{C}$ & $\begin{array}{c}\text { Chromosome } 1 ; 5^{\prime} \text { near gene; } \\
\text { Homo sapiens }\end{array}$ & Bipolar disease & [69] \\
\hline \multirow{4}{*}{ Bmal1 } & rs4757144 & $\mathrm{G}>\mathrm{A}$ & $\begin{array}{l}\text { Chromosome 11; intron; Homo } \\
\text { sapiens }\end{array}$ & Infertility and bipolar disease & {$[31,69]$} \\
\hline & rs1481892 & $\mathrm{G}>\mathrm{C}$ & $\begin{array}{l}\text { Chromosome } 11 \text {; intron; Homo } \\
\text { sapiens }\end{array}$ & Bipolar disease & [69] \\
\hline & rs1982350 & $A>G$ & $\begin{array}{l}\text { Chromosome 11; intron; Homo } \\
\text { sapiens }\end{array}$ & Bipolar disease & [69] \\
\hline & rs 2279287 & $\mathrm{~T}>\mathrm{C}$ & $\begin{array}{l}\text { Chromosome } 11 \text {; near-Gene } 5^{\prime} \text {; } \\
\text { Homo sapiens }\end{array}$ & Seasonal affective disorder & {$[70]$} \\
\hline Cryl & rs2287161 & $\mathrm{G}>\mathrm{C}$ & $\begin{array}{l}\text { Chromosome 12; upstream } \\
\text { variant } 2 \mathrm{~KB} \text {; Homo sapiens }\end{array}$ & Depression disease & {$[30]$} \\
\hline \multirow{2}{*}{ Cry 2} & $r s 4132063$ & $\mathrm{C}>\mathrm{T}$ & Chromosome 11; Homo sapiens & Depression disease & {$[71]$} \\
\hline & rs10838524 & $A>G$ & Chromosome 11; Homo sapiens & Depression disease & {$[71]$} \\
\hline Tef & rs738499 & $\mathrm{G}>\mathrm{T}$ & $\begin{array}{c}\text { Chromosome } 22 \text {; intron } \\
\text { upstream variant } 2 \mathrm{~KB} \text {; Homo } \\
\text { sapiens }\end{array}$ & Depression disease & [30] \\
\hline \multirow{2}{*}{ TIM } & rs2291739 & $\mathrm{G}>\mathrm{A} / \mathrm{C}$ & $\begin{array}{l}\text { Chromosome } 12 \text {; exon; Homo } \\
\text { sapiens }\end{array}$ & Unipolar disease & {$[66]$} \\
\hline & rs11171856 & $\mathrm{C}>\mathrm{T}$ & $\begin{array}{c}\text { Chromosome } 12 \text {; intron; Homo } \\
\text { sapiens }\end{array}$ & Unipolar disease & {$[66]$} \\
\hline
\end{tabular}

variants rs1801260 and rs11932595 showed a major risk of developing a bipolar disorder ranging between 45 and 37\%, respectively, in comparison to a patients without polymorphism (OR 1.45 and 1.37, resp.). In the same study, it was also observed that the polymorphisms rs2291739 and rs11171856 from TIM gene are associated with unipolar disease, with a risk ranging between 37 and $40 \%$ in comparison to a patient without polymorphism (OR 1.37 and 1.40, resp.). Similarly, Bmal1 polymorphisms $r s 1160996 \mathrm{C} / \mathrm{rs} 11022779 \mathrm{G} / \mathrm{rs} 1122780 \mathrm{~T}$ (haplotype) are associated with mood disorders [66] and bipolar disease $[29,66]$. It has also been seen that the bipolar pathologies are associated with other genetic variations of Bmall gene ( $r s 4757144, r s 1982350$, and $r$ s1481892) and the negative regulator Per3 (rs2859387) [69]. Curiously, a study performed an Indian families reported the Bmall polymorphisms rs2279287 are associated with seasonal affective disorder [70].

In addition, the gene variant of Cry2 gene (rs4132063) [71] and deletion/insertion of 54 base pair sequences on Per3 gene (rs57875989) [67] may also be contributing to mood disorders via increased risk of developing bipolar disease. For example, a study in South India showed the prevalence of five repeat homozygotes from rs57875989 is associated with bipolar disease (OR 1.72) but not with schizophrenia [68].

At the level of depressive pathologies, a study performed in China compared 485 subjects (control) to 105 patients suffering from a depression disorder. The genotyping for clock genes showed that the variants of Cry1 (rs2287161) and Cry2 (rs10838524) are correlated to the depression disease with an odds ratio of $1.75(P=0.012)$, which suggests that a patient with the allele has 1.75 times more risk of developing depression [30]. Moreover the authors detected a single nucleotide polymorphism for TEF gene, the variant $r s 738499$, is associated with 2.22 times more risk of development of depression (odds ratio of 2.22. $P<0.001$ ) than people not carrying the TEF polymorphism [30].

Finally, in a study performed in young adults, the risk of excessive intake of alcohol is minor when the polymorphism of Per2 gene rs56013859 is present, suggesting a possible protector role for allelic variation of clock genes in addictions 
[34]. In fact, this suggests that some polymorphisms are not negative for our health and it is necessary to study them in greater depth.

\section{Clock Genes and Cancer}

Cellular proliferation is a critical event for the survival and restitution of tissues of all living things and the circadian system is capable of delivering temporary information to the cell cycle [102-104]. However, an uncontrolled cellular proliferation and an excessive tissue growth are observed by an altered cellular cycle during cancer [105], a pathology that showed a higher incidence in patients exposed to an impaired circadian system such as a shiftwork $[106,107]$. The cell cycle is a finely regulated process from a cell that is capable of generating multiple cells through a series of cell divisions [101], including four critical and successive steps named G1 phase (growth phase 1), S phase (synthesis), G2 (growth phase 2), and $M$ phase (mitosis) [108]. During the cell cycle, cyclin-dependent kinases (CDK) are critical for the transition between different stages, for example, cdc2 plus cyclin B protein kinase form the complex CDK1 which regulates G2/M transition $[108,109]$. During DNA replication, there are a number of controls or checkpoints that are critical in the cell cycle when DNA damage is detected: the activation of the Rad protein, which induces the action of CDs 1 proteins, is triggered, as well as Chk1 which are involved in cell cycle arrest via action of Wee-1 and Mik-1 proteins [109].

Partial hepatectomy induces hepatocytes to enter the cell division for liver regeneration. However, the efficiency of this process changes depending on the time of the day when the lesion occurred. A lesion in the liver, occurring during the last light hours, induced a massive entry to $\mathrm{M}$ phase compared to a lesion which occurs early in the morning, which shows that the hour of surgery and the circadian system are critical for liver regeneration [20]. Similarly, oral mucosa is a highly proliferative tissue and it showed a circadian expression of clock genes Bmal1, Perl, and Cryl and thymidylate synthase activity, critical for DNA synthesis during phase S. Curiously, the peak of Perl mRNA precedes the peak of thymidylate synthase activity [110], which suggests that the circadian system modulates the cellular proliferation in mucosa.

Wee-1 gene regulates cellular proliferation, and its promoter has three conserved sequence CACGTG (E-box) critical for the circadian expression of Wee-1 [20]. Its protein is capable of inactivating the cdc2-cyclin B complex via phosphorylation which inhibits transition between G2/M. Curiously, knock-down of Bmal1 in carcinoma cells of the colon (c26 cells), fibroblast cells (L929 cell), and intestine epithelial cells (IECs) produces cellular proliferation in vitro and increments the size of tumor cells injected subcutaneously, via the inhibition of apoptosis and the reduction of the time transition between G2/M [102], reduction of p53 and Wee-1 expression [103]. Moreover, the knock-out for clock genes Bmal1 y Per2 in mice previously exposed to gamma radiation caused in mice hyperplasic growth and development of lymphoma, hepatic carcinomas, ovary tumors, and osteosarcomas via reduction of p53 expression
[103]. A precedent that reinforces the idea that clock genes can be modulators of cellular cycle via Wee-1 and p53 proteins.

At the genetic component level, different studies reveal the importance of the polymorphic variant of clock genes (see Table 3) and how the Chrono-type modulates the risk of cancer, such as observed in breast cancer, in which the risk is more elevated in premenopausal women (OR, 2.43 and 2.55; resp.) [77]. Similarly, women showed evening or night preference such as shown in the case of a study performed on Norwegian nurses working in night shift which revealed two polymorphisms associated with breast cancer. The risk is incremented when women spend more time working during night hours, but this risk is higher when women have the alleles for Bmal1 rs2290035 (OR 1.91), rs969485 (OR 1.64), and rs3903529 (OR 2.77) or variant $r s 3750420$ (OR 1.6) of Roreb gene [84]. Similarly, an incremented risk is associated with breast cancer in women from France when they have the allele rs11932595 in Clock gene (OR = 0.74) or in Connecticut (USA) when they have the polymorphisms rs7698022 (OR 1.34) and rs1048004 (OR, 1.43) [73]. Curiously, when Norwegian nurses are exposed to shift work during four nights, they showed three times more risk (OR 2.75) of developing breast cancer when they were carrying Clock polymorphism rs11133373, which suggests that the disruption of endogenous circadian rhythm by polymorphism associated with Clock genes increases the risk of cancer [84]. Moreover, Clock gene expression is induced in breast tissue from patients with breast cancer; this expression is associated with hypomethylation of Clock gene. The silencing of Clock gene lowered when women carry polymorphisms associated with cancer such as rs10448004 and rs7698022, which suggests that Clock gene is a critical protagonist of cancer development [73].

At level of colorectal cancer, a strong correlation is detected between cancer and the genetic component of the circadian system. For example, a polymorphism in the Clock gene $(r s 1801260)$ showed a major prevalence in a cancer patient $(P<0.0001, \mathrm{OR}=1.78$ for $\mathrm{C}$-allele $)$ compared to a control patient [32]. Similarly, a screening performed in South Carolina, USA, showed that a variation by deletion/insertion of a 54 base pair sequence on Per3 gene (rs57875989) is associated with a higher risk of colorectal adenoma formation with odds ratio within 2.1-5.1 [78]. Moreover, a population study performed on the residents of King County, Washington (USA), detected six different types of polymorphism, which are significantly associated with the risk and aggressiveness of prostate cancer. These genetics variants are $r s 1012477$ for Per3 (OR 1.3), rs7602358 for Per2 (OR 1.24), and rs2289591 in Perl (OR 1.7) [76]. Similarly, a genotyping of a patient with prostate cancer showed a strong correlation between Cryl polymorphisms rs7297614, rs1921126, and rs12315175 and fatal prostate cancer (OR mean within 1.5-2) [85] and a study conducted in China showed that the Cry2 variant rs1401417 and the deletion/insertion of 54 base pair sequences on Per3 gene (rs57875989) were associated with a major risk of developing prostate cancer (OR; 1.7 and 1.3, resp.) [79].

A study performed in Brazilian patients with pulmonary cancer showed a strong correlation of Per3 polymorphism rs228644 and the risk of cancer (OR 1.99). Moreover, the 
TABLE 3: Polymorphisms of clock genes associated with cancer.

\begin{tabular}{|c|c|c|c|c|c|}
\hline Gene & SNPs & Variation & Localization & Pathology & Reference \\
\hline \multirow{7}{*}{ Clock } & $r s 1801260$ & $\mathrm{~T}>\mathrm{C}$ & Chromosome 4; $3^{\prime}$ UTR; Homo sapiens & Colorectal cancer & {$[32]$} \\
\hline & rs11932595 & $A>G$ & Chromosome 4; intron; Homo sapiens & Breast cancer & {$[72]$} \\
\hline & rs7698022 & $\mathrm{C}>\mathrm{A}$ & Chromosome 4; intron; Homo sapiens & Breast cancer & [73] \\
\hline & rs11932595 & $A>G$ & Chromosome 4; intron; Homo sapiens & Breast cancer & [73] \\
\hline & rs1048004 & $\mathrm{G}>\mathrm{T}$ & Chromosome 4; 3' UTR; Homo sapiens & Breast cancer & [73] \\
\hline & $r s 3805151$ & $\mathrm{C}>\mathrm{T}$ & Chromosome 4; intron-6; Homo sapiens & Breast cancer & [74] \\
\hline & rs11133391 & $\mathrm{T}>\mathrm{C}$ & Chromosome 4; intron; Homo sapiens & Glioma & [75] \\
\hline \multirow[b]{2}{*}{ Per1 } & $r s 2585405$ & $\mathrm{C}>\mathrm{G}$ & Chromosome 17; missense; Homo sapiens & Glioma & [75] \\
\hline & rs2289591 & $\mathrm{G}>\mathrm{T}$ & $\begin{array}{c}\text { Chromosome } 17 ; 5^{\prime} \text { near gene; Homo } \\
\text { sapiens }\end{array}$ & Prostate cancer & {$[76]$} \\
\hline \multirow{2}{*}{ Per2 } & $r s 7602358$ & $\mathrm{G}>\mathrm{T}$ & Chromosome 2; intron; Homo sapiens & Prostate cancer & [76] \\
\hline & rs934945: & $\mathrm{G}>\mathrm{A}$ & Chromosome 2; Exon-23; Homo sapiens & Breast cancer & [74] \\
\hline \multirow{4}{*}{ Per3 } & rs1012477 & $\mathrm{G}>\mathrm{C}$ & $\begin{array}{c}\text { Chromosome } 1 ; 5^{\prime} \text { near gene; Homo } \\
\text { sapiens }\end{array}$ & Prostate cancer & {$[76]$} \\
\hline & rs57875989 & Deletion/insertion & $\begin{array}{c}\text { Chromosome } 1 ; 5^{\prime} \text { near gene; Homo } \\
\text { sapiens }\end{array}$ & $\begin{array}{c}\text { Colorectal cancer, } \\
\text { breast cancer } \\
\text { Prostate cancer }\end{array}$ & {$[74,77-81]$} \\
\hline & rs228669 & $\mathrm{T}>\mathrm{C}$ & Chromosome 1; CDS; Homo sapiens & $\begin{array}{l}\text { Hepatocellular } \\
\text { carcinoma }\end{array}$ & {$[82]$} \\
\hline & rs 228644 & $\mathrm{G}>\mathrm{A}$ & Chromosome 1; intron; Homo sapiens & Lung cancer & {$[83]$} \\
\hline \multirow{2}{*}{ Bmal1 } & $r s 2290035$ & $\mathrm{~T}>\mathrm{A}$ & Chromosome 11; intron; Homo sapiens & Breast cancer & {$[84]$} \\
\hline & rs969485 & $\mathrm{G}>\mathrm{A}$ & Chromosome 11; intron; Homo sapiens & Breast cancer & {$[84]$} \\
\hline \multirow{6}{*}{ Cryl } & rs3809236 & $\mathrm{C}>\mathrm{T}$ & Chromosome 12; 5' UTR Homo sapiens & $\begin{array}{l}\text { Hepatocellular } \\
\text { carcinoma }\end{array}$ & {$[82]$} \\
\hline & rs 1056560 & $\mathrm{~T}>\mathrm{G}$ & Chromosome 12; exon-13 Homo sapiens & Breast cancer & {$[74]$} \\
\hline & rs7297614 & $\mathrm{C}>\mathrm{T}$ & Chromosome 12; 5' UTR Homo sapiens & Prostate cancer & {$[85]$} \\
\hline & rs1921126 & $\mathrm{C}>\mathrm{T}$ & Chromosome 12; intron Homo sapiens & Prostate cancer & {$[85]$} \\
\hline & rs12315175 & $\mathrm{T}>\mathrm{C}$ & Chromosome 12; 5' UTR Homo sapiens & Prostate cancer & {$[85]$} \\
\hline & rs12315175 & $\mathrm{T}>\mathrm{C}$ & Chromosome 12 ; noncoding sequence & Glioma & {$[75]$} \\
\hline \multirow{5}{*}{ Cry2 } & rs11038689 & $\mathrm{A}>\mathrm{G}$ & Chromosome 11; intron; Homo sapiens & Breast cancer & {$[84]$} \\
\hline & rs1401417 & $\mathrm{C}>\mathrm{G}$ & Chromosome 11; intron; Homo sapiens & $\begin{array}{l}\text { Breast cancer } \\
\text { Prostate cancer }\end{array}$ & {$[79,84]$} \\
\hline & rs11038689 & $A>G$ & Chromosome 11; intron; Homo sapiens & $\begin{array}{l}\text { Non-Hodgkin's } \\
\text { lymphoma }\end{array}$ & {$[86]$} \\
\hline & rs7123390 & $\mathrm{G}>\mathrm{A}$ & Chromosome 11; intron; Homo sapiens & $\begin{array}{l}\text { Non-Hodgkin's } \\
\text { lymphoma }\end{array}$ & {$[86]$} \\
\hline & rs1401417 & $\mathrm{C}>\mathrm{G}$ & Chromosome 11; intron; Homo sapiens & $\begin{array}{l}\text { Non-Hodgkin's } \\
\text { lymphoma }\end{array}$ & {$[86]$} \\
\hline \multirow{2}{*}{ TIM } & $r s 7302060$ & $\mathrm{~T}>\mathrm{C}$ & Chromosome 12; intron; Homo sapiens & Breast cancer & [87] \\
\hline & rs 2291738 & $\mathrm{~T}>\mathrm{C}$ & Chromosome 12; intron; Homo sapiens & Breast cancer & [87] \\
\hline \multirow{2}{*}{$R O R-b$} & $r s 3750420$ & $\mathrm{C}>\mathrm{T}$ & Chromosome 9; intron; Homo sapiens & Breast cancer & {$[84]$} \\
\hline & $r s 3903529$ & $\mathrm{~T}>\mathrm{A}$ & Chromosome 9; intron; Homo sapiens & Breast cancer & {$[84]$} \\
\hline
\end{tabular}

authors reported the ancestral haplotypes for Per3 rs228729, rs228727, rs707467, rs228644, and rs10462020 are associated with a higher cancer frequency [83]; similarly, a meta-analysis performed by literature search showed that the variant insertion/deletion of Per3 rs57875989 is associated with an increase of cancer susceptibility in about $17 \%$ [80] or $70 \%$ [81]. In a similar way, a soft risk is associated with breast cancer in premenopausal women from India [77], which suggests there is a relation between Per3 and cellular proliferation.

The frequency analysis of 1,538 breast cancer cases and 1,605 controls in China for clock gene variants showed the strong associations between three SNPs in circadian clock genes and the risk of developing breast cancer. The variants for Cryl rs1056560 are correlated to cancer, which elevate the risk in about 11\% (OR 1.11); Per2 rs934945 in about $15 \%$ (OR 1.15); and Clock rs3805151 in about 35\% (OR 1.35) [74]. In contrast, TIM protection for breast cancer development is detected in patients that carry the C-allele of $r s 7302060$ (OR, 0.54). The $\mathrm{G}$ allele of rs2291738 and the C-allele of rs7302060 are associated with reduced risk of breast cancer among estrogen receptor $(-)$ or progesterone receptor (-) positive breast cancer cases (OR, 0.46 and 0.36, resp.) [87].

The exogenous expression of human clock in cell lines of colorectal carcinoma induces the cellular proliferation in 
about $28 \%$. In contrast, knock-down of endogenous Clock gene expression inhibits the cell proliferation in about $34 \%$ [111]. Moreover, exogenous Clock inhibits the apoptosis (42\% reduction) via inhibition on apoptosis associated proteins expression of Bax and Bid and the increase of phosphorylation of Akt [111]. In vivo experiments by xenograft transplant of colorectal carcinoma cell line transduced with clock increase the tumor volume and tumor weight in about $61 \%$ and a $91 \%$, respectively [111]. However, the pharmacological inhibition of Cry in human breast cancer by treatment with pharmacological agent KS15 [112] inhibits the proliferation and cell viability by stimulation of Wee-1 expression [112] and stimulates the activity of heterodimer complex Bmall:Clock $[112,113]$.

Curiously, two polymorphisms for clock gene Cry2, rs11038689 and rs1401417, have a protective action over the mammary cancer [84], which suggests that not all polymorphisms associated with clock genes are negative for our health.

Non-Hodgkin's lymphoma is characterized by lymphoproliferation and advanced clinical stages, invasion to other tissues, and death. The estimated deaths from non-Hodgkin's lymphoma in the United States amounted to 19,790 during 2015 [114]. Analysis of Cry2 variants showed the polymorphisms rs11038689, rs7123390, and rs1401417 increase the risk of lymphoma $(O R, 2.34 ; 2.40$ and 2.97, resp.) [86]. Moreover, a minor association of clock gene variants and glioma is detected for Per1 rs2585405, Clock rs11133391, and Cry1 rs12315175 (OR, 1.16; 1.08 and 1.02, resp.) [75].

Genotyping of Han Chinese patients diagnosed with primary hepatocellular carcinoma showed an association between single SNPs of Per3 rs228669 and Cry1 rs3809236 with odds ratio of 1.41 and 1.26 , respectively [82]. These precedents reinforce the idea that clock genes can be modulators of cellular cycle and that modulates the risk of cancer.

\section{Conclusion}

The circadian system is a supraphysiological system which modulates different physiological systems, and any alteration of this can have a negative impact on human health. Different chronodisruptors have been described in literature such as light/dark pattern and inhibition of melatonin production as occurs in shifts work. However, other factors can be contributing on a minor scale, such as mealtimes or a genetic component.

The relevance of the genetic variation of clock genes and how it can interact with the environment is unknown. But it has been described that the genetic component in the population predisposes the development of different pathologies such as diabetes, dyslipidemias, obesity, mood disorders, and addiction, all of which suggest the importance of this system to our health. However, it is also necessary to say that the genetic component could be protecting our health such as in the case of polymorphisms associated with Per2 and Cry 2 genes in diabetes, alcohol intake, and cancer.

These findings will need to be implemented and evaluated at the genetic interaction level and also the way in which the environment factors trigger the expression of these pathologies will be examined. Finally, prospective studies are necessary to assess the predictive potential of these markers and to implement early treatment with consequent cost reduction for the health system.

\section{Glossary}

Bmall: Aryl hydrocarbon receptor nuclear translocator-like protein 1

Clock: Circadian locomotor output cycles kaput

Per: $\quad$ Homolog of period, drosophila

E-box: Promoter sequence for binding of clock-Bmall complex (CACGTG)

DBP: Albumin D-site-binding protein

VEGF: Vascular endothelial growth factor

StAR: $\quad$ Steroidogenic acute regulatory protein

$3 \beta$-HSD: 3-Beta-hydroxysteroid dehydrogenase.

\section{Competing Interests}

None of the authors have a conflict of interests.

\section{Acknowledgments}

This study was funded by Conicyt 79112027 (Chile) and Beca Postgrado UBB-2015.

\section{References}

[1] M. Serón-Ferré, M. L. Forcelledo, C. Torres-Farfan et al., "Impact of chronodisruption during primate pregnancy on the maternal and newborn temperature rhythms," PLOS ONE, vol. 8, no. 2, Article ID e57710, 2013.

[2] F. J. Valenzuela, C. Torres-Farfan, H. G. Richter et al., "Clock gene expression in adult primate suprachiasmatic nuclei and adrenal: is the adrenal a peripheral clock responsive to melatonin?” Endocrinology, vol. 149, no. 4, pp. 1454-1461, 2008.

[3] D. Feng and M. A. Lazar, "Clocks, metabolism, and the epigenome," Molecular Cell, vol. 47, no. 2, pp. 158-167, 2012.

[4] S. M. Reppert and D. R. Weaver, "Coordination of circadian timing in mammals," Nature, vol. 418, no. 6901, pp. 935-941, 2002.

[5] M. L. Dubocovich, P. Delagrange, D. N. Krause, D. Sugden, D. P. Cardinali, and J. Olcese, "International union of basic and clinical pharmacology. LXXV. Nomenclature, classification, and pharmacology of $\mathrm{G}$ protein-coupled melatonin receptors," Pharmacological Reviews, vol. 62, no. 3, pp. 343-380, 2010.

[6] J. S. Takahashi, H.-K. Hong, C. H. Ko, and E. L. McDearmon, "The genetics of mammalian circadian order and disorder: implications for physiology and disease," Nature Reviews Genetics, vol. 9, no. 10, pp. 764-775, 2008.

[7] H. Duez and B. Staels, "Rev-erb- $\alpha$ : an integrator of circadian rhythms and metabolism," Journal of Applied Physiology, vol. 107, no. 6, pp. 1972-1980, 2009.

[8] L. Yin, N. Wu, J. C. Curtin et al., "Rev-erb $\alpha$, a heme sensor that coordinates metabolic and circadian pathways," Science, vol. 318, no. 5857, pp. 1786-1789, 2007.

[9] N. Preitner, F. Damiola, Luis-Lopez-Molina et al., “The orphan nuclear receptor REV-ERB $\alpha$ controls circadian transcription 
within the positive limb of the mammalian circadian oscillator," Cell, vol. 110, no. 2, pp. 251-260, 2002.

[10] M. M. Bellet, R. Orozco-Solis, S. Sahar, K. Eckel-Mahan, and P. Sassone-Corsi, "The time of metabolism: $\mathrm{NAD}^{+}, \mathrm{SIRT} 1$, and the circadian clock," Cold Spring Harbor Symposia on Quantitative Biology, vol. 76, pp. 31-38, 2011.

[11] X. Li, "SIRT1 and energy metabolism," Acta Biochimica et Biophysica Sinica, vol. 45, no. 1, pp. 51-60, 2013.

[12] J. Bass, "Circadian topology of metabolism," Nature, vol. 491, no. 7424, pp. 348-356, 2012.

[13] C. Liu, S. Li, T. Liu, J. Borjigin, and J. D. Lin, “Transcriptional coactivator PGC- $1 \alpha$ integrates the mammalian clock and energy metabolism," Nature, vol. 447, no. 7143, pp. 477-481, 2007.

[14] L. A. Solt, Y. Wang, S. Banerjee et al., "Regulation of circadian behaviour and metabolism by synthetic REV-ERB agonists," Nature, vol. 485, no. 7396, pp. 62-68, 2012.

[15] H. R. Ueda, W. Chen, A. Adachi et al., "A transcription factor response element for gene expression during circadian night," Nature, vol. 418, no. 6897, pp. 534-539, 2002.

[16] F. Gachon, P. Fonjallaz, F. Damiola et al., "The loss of circadian PAR bZip transcription factors results in epilepsy," Genes and Development, vol. 18, no. 12, pp. 1397-1412, 2004.

[17] Z. A. Khatib, T. Inaba, M. Valentine, and A. T. Look, "Chromosomal localization and cDNA cloning of the human DBP and TEF genes," Genomics, vol. 23, no. 2, pp. 344-351, 1994.

[18] E. Frigato, L. Lunghi, M. E. Ferretti, C. Biondi, and C. Bertolucci, "Evidence for circadian rhythms in human trophoblast cell line that persist in hypoxia," Biochemical and Biophysical Research Communications, vol. 378, no. 1, pp. 108-111, 2009.

[19] C. Torres-Farfan, L. Abarzua-Catalan, F. J. Valenzuela et al., "Cryptochrome 2 expression level is critical for adrenocorticotropin stimulation of cortisol production in the capuchin monkey adrenal," Endocrinology, vol. 150, no. 6, pp. 2717-2722, 2009.

[20] T. Matsuo, S. Yamaguchi, S. Mitsui, A. Emi, F. Shimoda, and H. Okamura, "Control mechanism of the circadian clock for timing of cell division in vivo," Science, vol. 302, no. 5643, pp. 255-259, 2003.

[21] L. Fu and N. M. Kettner, "The circadian clock in cancer development and therapy," Progress in Molecular Biology and Translational Science, vol. 119, pp. 221-282, 2013.

[22] J. Hansen, "Risk of breast cancer after night- and shift work: current evidence and ongoing studies in Denmark," Cancer Causes and Control, vol. 17, no. 4, pp. 531-537, 2006.

[23] S. A. Huisman, M. Oklejewicz, A. R. Ahmadi et al., "Colorectal liver metastases with a disrupted circadian rhythm phase shift the peripheral clock in liver and kidney," International Journal of Cancer, vol. 136, no. 5, pp. 1027-1032, 2015.

[24] A. J. Ditisheim, C. Dibner, J. Philippe, and A. Pechére-Bertschi, "Biological rhythms and preeclampsia," Frontiers in Endocrinology, vol. 4, article 47, 2013.

[25] S. Mayor, "Shift work is associated with increased risk of type 2 diabetes, study shows," British Medical Journal, vol. 349, Article ID g4804, 2014.

[26] S. M. W. Rajaratnam, M. E. Howard, and R. R. Grunstein, "Sleep loss and circadian disruption in shift work: health burden and management," The Medical Journal of Australia, vol. 199, no. 8, pp. S11-S15, 2013.

[27] FastStats, Centers for Disease Control and Prevention (CDC), 2016, http://www.cdc.gov/nchs/fastats/leading-causes-of-death .htm.
[28] J. Boivin, L. Bunting, J. A. Collins, and K. G. Nygren, "International estimates of infertility prevalence and treatment-seeking: potential need and demand for infertility medical care," Human Reproduction, vol. 22, no. 6, pp. 1506-1512, 2007.

[29] D. Nettle and M. Bateson, "The evolutionary origins of mood and its disorders," Current Biology, vol. 22, no. 17, pp. R712-R721, 2012.

[30] P. Hua, W. Liu, D. Chen et al., "Cryl and Tef gene polymorphisms are associated with major depressive disorder in the Chinese population," Journal of Affective Disorders, vol. 157, pp. 100-103, 2014.

[31] A. Hodžić, M. Ristanović, B. Zorn et al., "Genetic variation in circadian rhythm genes CLOCK and ARNTL as risk factor for male infertility," PLoS ONE, vol. 8, no. 3, Article ID e59220, 2013.

[32] T. Karantanos, G. Theodoropoulos, M. Gazouli et al., "Association of the clock genes polymorphisms with colorectal cancer susceptibility," Journal of Surgical Oncology, vol. 108, no. 8, pp. 563-567, 2013.

[33] K. I. Pappa, M. Gazouli, E. Anastasiou, Z. Iliodromiti, A. Antsaklis, and N. P. Anagnou, "The major circadian pacemaker ARNT-like protein-1 (BMAL1) is associated with susceptibility to gestational diabetes mellitus," Diabetes Research and Clinical Practice, vol. 99, no. 2, pp. 151-157, 2013.

[34] D. Blomeyer, A. F. Buchmann, J. Lascorz et al., "Association of PER2 genotype and stressful life events with alcohol drinking in young adults," PLoS ONE, vol. 8, no. 3, Article ID e59136, 2013.

[35] H. G. Richter, C. Torres-Farfán, P. P. Rojas-García, C. Campino, F. Torrealba, and M. Serón-Ferré, "The circadian timing system: making sense of day/night gene expression," Biological Research, vol. 37, no. 1, pp. 11-28, 2004.

[36] A. Kalsbeek, S. la Fleur, and E. Fliers, "Circadian control of glucose metabolism," Molecular Metabolism, vol. 3, no. 4, pp. 372-383, 2014.

[37] L. Chen and G. Yang, "Recent advances in circadian rhythms in cardiovascular system," Frontiers in Pharmacology, vol. 6, article 71, 2015.

[38] F. Hatanaka, C. Matsubara, J. Myung et al., "Genome-wide profiling of the core clock protein BMAL1 targets reveals a strict relationship with metabolism," Molecular and Cellular Biology, vol. 30, no. 24, pp. 5636-5648, 2010.

[39] P. L. Huang, "A comprehensive definition for metabolic syndrome," Disease Models and Mechanisms, vol. 2, no. 5-6, pp. 231237, 2009.

[40] H. Beltrán-Sánchez, M. O. Harhay, M. M. Harhay, and S. McElligott, "Prevalence and trends of metabolic syndrome in the adult U.S. population, 1999-2010," Journal of the American College of Cardiology, vol. 62, no. 8, pp. 697-703, 2013.

[41] I. Martin-Timon, C. Sevillano-Collantes, A. Segura-Galindo, and F. J. del Canizo-Gomez, "Type 2 diabetes and cardiovascular disease: have all risk factors the same strength?" World Journal of Diabetes, vol. 5, no. 4, pp. 444-470, 2014.

[42] D. Lebeche, A. J. Davidoff, and R. J. Hajjar, "Interplay between impaired calcium regulation and insulin signaling abnormalities in diabetic cardiomyopathy," Nature Clinical Practice Cardiovascular Medicine, vol. 5, no. 11, pp. 715-724, 2008.

[43] F. Westermeier, P. J. Sáez, R. Villalobos-Labra, L. Sobrevia, and M. Farías-Jofré, "Programming of fetal insulin resistance in pregnancies with maternal obesity by ER stress and inflammation," BioMed Research International, vol. 2014, Article ID 917672, 13 pages, 2014. 
[44] K. Nerenberg, S. S. Daskalopoulou, and K. Dasgupta, "Gestational diabetes and hypertensive disorders of pregnancy as vascular risk signals: an overview and grading of the evidence," Canadian Journal of Cardiology, vol. 30, no. 7, pp. 765-773, 2014.

[45] D. J. Withers, D. J. Burks, H. H. Towery, S. L. Altamuro, C. L. Flint, and M. F. White, "Irs-2 coordinates Igf-1 receptormediated $\beta$-cell development and peripheral insulin signalling," Nature Genetics, vol. 23, no. 1, pp. 32-40, 1999.

[46] P. Cohen, "The twentieth century struggle to decipher insulin signalling," Nature Reviews Molecular Cell Biology, vol. 7, no. 11, pp. 867-873, 2006.

[47] Y. Gan, C. Yang, X. Tong et al., "Shift work and diabetes mellitus: a meta-analysis of observational studies," Occupational and Environmental Medicine, vol. 72, no. 1, pp. 72-78, 2015.

[48] N. A. Shamsi, M. D. Salkeld, L. Rattanatray et al., "Metabolic consequences of timed feeding in mice," Physiology and Behavior, vol. 128, pp. 188-201, 2014.

[49] A. Shostak, J. Meyer-Kovac, and H. Oster, "Circadian regulation of lipid mobilization in white adipose tissues," Diabetes, vol. 62, no. 7, pp. 2195-2203, 2013.

[50] J. Lee, M.-S. Kim, R. Li et al., "Loss of Bmall leads to uncoupling and impaired glucose-stimulated insulin secretion in $\beta$-cells," Islets, vol. 3, no. 6, pp. 381-388, 2011.

[51] B. Marcheva, K. M. Ramsey, E. D. Buhr et al., "Disruption of the clock components CLOCK and BMAL1 leads to hypoinsulinaemia and diabetes," Nature, vol. 466, no. 7306, pp. 627-631, 2010.

[52] J. M. Carvas, A. Vukolic, G. Yepuri et al., "Period2 gene mutant mice show compromised insulin-mediated endothelial nitric oxide release and altered glucose homeostasis," Frontiers in Physiology, vol. 3, article 337, 2012.

[53] M. A. Kelly, S. D. Rees, Z. L. Hydriem et al., "Circadian gene variants and susceptibility to type 2 diabetes: a pilot study," PLoS ONE, vol. 7, no. 4, Article ID e32670, 2012.

[54] F. Renström, R. W. Koivula, T. V. Varga et al., "Season-dependent associations of circadian rhythm-regulating loci (CRY1, CRY2 and MTNR1B) and glucose homeostasis: the GLACIER Study," Diabetologia, vol. 58, no. 5, pp. 997-1005, 2015.

[55] P. Y. Woon, P. J. Kaisaki, J. Bragança et al., "Aryl hydrocarbon receptor nuclear translocator-like (BMAL1) is associated with susceptibility to hypertension and type 2 diabetes," Proceedings of the National Academy of Sciences of the United States of America, vol. 104, no. 36, pp. 14412-14417, 2007.

[56] M. Yamaguchi, H. Uemura, K. Arisawa et al., "Association between brain-muscle-ARNT-like protein-2 (BMAL2) gene polymorphism and type 2 diabetes mellitus in obese Japanese individuals: a cross-sectional analysis of the Japan Multiinstitutional Collaborative Cohort Study," Diabetes Research and Clinical Practice, vol. 110, no. 3, pp. 301-308, 2015.

[57] R. Karthikeyan, G. Marimuthu, M. Sooriyakumar et al., "Per3 length polymorphism in patients with type 2 diabetes mellitus," Hormone Molecular Biology and Clinical Investigation, vol. 18, no. 3, pp. 145-149, 2014.

[58] R. Karthikeyan, G. Marimuthu, D. W. Spence et al., "Should we listen to our clock to prevent type 2 diabetes mellitus?" Diabetes Research and Clinical Practice, vol. 106, no. 2, pp. 182-190, 2014.

[59] K. Tsuzaki, K. Kotani, Y. Sano, S. Fujiwara, K. Takahashi, and N. Sakane, "The association of the Clock 3111 T/C SNP with lipids and lipoproteins including small dense low-density lipoprotein: results from the Mima study," BMC Medical Genetics, vol. 11, article 150, 2010.
[60] H. Uemura, S. Katsuura-Kamano, M. Yamaguchi et al., "Variant of the clock circadian regulator (CLOCK) gene and related haplotypes are associated with the prevalence of type 2 diabetes in the Japanese population," Journal of Diabetes, 2015.

[61] D. Corella, E. M. Asensio, O. Coltell et al., "CLOCK gene variation is associated with incidence of type-2 diabetes and cardiovascular diseases in type- 2 diabetic subjects: dietary modulation in the PREDIMED randomized trial," Cardiovascular Diabetology, vol. 15, no. 1, article 4, 2016.

[62] D. Ye, S. Cai, X. Jiang et al., "Associations of polymorphisms in circadian geneswith abdominal obesity in Chinese adult population," Obesity Research \& Clinical Practice, 2016.

[63] F. Gomez-Delgado, A. Garcia-Rios, J. F. Alcala-Diaz et al., "Chronic consumption of a low-fat diet improves cardiometabolic risk factors according to the CLOCK gene in patients with coronary heart disease," Molecular Nutrition \& Food Research, vol. 59, no. 12, pp. 2556-2564, 2015.

[64] H. S. Dashti, J. L. Follis, C. E. Smith et al., "Habitual sleep duration is associated with $\mathrm{BMI}$ and macronutrient intake and may be modified by CLOCK genetic variants," The American Journal of Clinical Nutrition, vol. 101, no. 1, pp. 135-143, 2015.

[65] V. Loria-Kohen, I. Espinosa-Salinas, H. Marcos-Pasero et al., "Polymorphism in the CLOCK gene may influence the effect of fat intake reduction on weight loss," Nutrition, vol. 32 , no. 4 , pp. 453-460, 2016.

[66] M. P. Dmitrzak-Weglarz, J. M. Pawlak, M. Maciukiewicz et al., "Clock gene variants differentiate mood disorders," Molecular Biology Reports, vol. 42, no. 1, pp. 277-288, 2015.

[67] S. Dallaspezia, C. Lorenzi, A. Pirovano, C. Colombo, E. Smeraldi, and F. Benedetti, "Circadian clock gene Per3 variants influence the postpartum onset of bipolar disorder," European Psychiatry, vol. 26, no. 3, pp. 138-140, 2011.

[68] R. Karthikeyan, G. Marimuthu, C. Ramasubramanian et al., "Association of Per3 length polymorphism with bipolar I disorder and schizophrenia," Neuropsychiatric Disease and Treatment, vol. 10, pp. 2325-2330, 2014.

[69] H. A. Mansour, J. Wood, T. Logue et al., "Association study of eight circadian genes with bipolar I disorder, schizoaffective disorder and schizophrenia," Genes, Brain and Behavior, vol. 5, no. 2, pp. 150-157, 2006.

[70] B. Rajendran and V. N. Janakarajan, "Circadian clock gene aryl hydrocarbon receptor nuclear translocator-like polymorphisms are associated with seasonal affective disorder: an Indian family study," Indian Journal of Psychiatry, vol. 58, no. 1, pp. 57-60, 2016.

[71] E. M. Byrne, A. C. Heath, P. A. F. Madden et al., "Testing the role of circadian genes in conferring risk for psychiatric disorders," American Journal of Medical Genetics Part B: Neuropsychiatric Genetics, vol. 165, no. 3, pp. 254-260, 2014.

[72] T. Truong, B. Liquet, F. Menegaux et al., "Breast cancer risk, nightwork, and circadian clock gene polymorphisms," Endocrine-Related Cancer, vol. 21, no. 4, pp. 629-638, 2014.

[73] A. E. Hoffman, C.-H. Yi, T. Zheng et al., "CLOCK in breast tumorigenesis: genetic, epigenetic, and transcriptional profiling analyses," Cancer Research, vol. 70, no. 4, pp. 1459-1468, 2010.

[74] H. Dai, L. Zhang, M. Cao et al., "The role of polymorphisms in circadian pathway genes in breast tumorigenesis," Breast Cancer Research and Treatment, vol. 127, no. 2, pp. 531-540, 2011.

[75] M. H. Madden, G. M. Anic, R. C. Thompson et al., "Circadian pathway genes in relation to glioma risk and outcome," Cancer Causes and Control, vol. 25, no. 1, pp. 25-32, 2014. 
[76] Y. Zhu, R. G. Stevens, A. E. Hoffman et al., “Testing the circadian gene hypothesis in prostate cancer: a population-based casecontrol study," Cancer Research, vol. 69, no. 24, pp. 9315-9322, 2009.

[77] M. D. Wirth, J. B. Burch, J. R. Hébert et al., "Case-control study of breast cancer in India: role of PERIOD3 clock gene length polymorphism and chronotype," Cancer Investigation, vol. 32, no. 7, pp. 321-329, 2014.

[78] M. Alexander, J. B. Burch, S. E. Steck et al., "Case-control study of the PERIOD3 clock gene length polymorphism and colorectal adenoma formation," Oncology Reports, vol. 33, no. 2, pp. 935-941, 2015.

[79] L. W. Chu, Y. Zhu, K. Yu et al., "Variants in circadian genes and prostate cancer risk: a population-based study in China," Prostate Cancer and Prostatic Diseases, vol. 11, no. 4, pp. 342348, 2008.

[80] P. Geng, J. Ou, J. Li et al., "Genetic association between PER3 genetic polymorphisms and cancer susceptibility: a metaanalysis," Medicine, vol. 94, no. 13, article e568, 2015.

[81] A. Grundy, J. M. Schuetz, A. S. Lai et al., "Shift work, circadian gene variants and risk of breast cancer," Cancer Epidemiology, vol. 37, no. 5, pp. 606-612, 2013.

[82] Z. Zhang, F. Ma, F. Zhou et al., "Functional polymorphisms of circadian negative feedback regulation genes are associated with clinical outcome in hepatocellular carcinoma patients receiving radical resection," Medical Oncology, vol. 31, no. 12, p. 179, 2014.

[83] P. Couto, D. Miranda, R. Vieira, A. Vilhena, L. De Marco, and L. Bastos-Rodrigues, "Association between CLOCK, PER3 and CCRN4L with non-small cell lung cancer in Brazilian patients," Molecular Medicine Reports, vol. 10, no. 1, pp. 435-440, 2014.

[84] S. Zienolddiny, A. Haugen, J.-A. S. Lie, H. Kjuus, K. H. Anmarkrud, and K. Kjærheim, "Analysis of polymorphisms in the circadian-related genes and breast cancer risk in Norwegian nurses working night shifts," Breast Cancer Research, vol. 15, no. 4, article R53, 2013.

[85] S. C. Markt, U. A. Valdimarsdottir, I. M. Shui et al., "Circadian clock genes and risk of fatal prostate cancer," Cancer Causes \& Control, vol. 26, no. 1, pp. 25-33, 2015.

[86] A. E. Hoffman, T. Zheng, R. G. Stevens et al., "Clock-cancer connection in non-Hodgkin's lymphoma: a genetic association study and pathway analysis of the circadian gene Cryptochrome 2," Cancer Research, vol. 69, no. 8, pp. 3605-3613, 2009.

[87] A. Fu, D. Leaderer, T. Zheng, A. E. Hoffman, R. G. Stevens, and Y. Zhu, "Genetic and epigenetic associations of circadian gene TIMELESS and breast cancer risk," Molecular Carcinogenesis, vol. 51, no. 12, pp. 923-929, 2012.

[88] K. Hwang, A. N. Yatsenko, C. J. Jorgez et al., "Mendelian genetics of male infertility," Annals of the New York Academy of Sciences, vol. 1214, pp. E1-E17, 2010.

[89] M. H. Johnson and M. L. Day, "Egg timers: how is developmental time measured in the early vertebrate embryo?" BioEssays: Biological Timing Mechanisms, vol. 22, no. 1, pp. 57-63, 2000.

[90] M. J. Boden, T. J. Varcoe, and D. J. Kennaway, "Circadian regulation of reproduction: from gamete to offspring," Progress in Biophysics and Molecular Biology, vol. 113, no. 3, pp. 387-397, 2013.

[91] A. F. Khattab, F. A. Mustafa, and P. J. Taylor, "The use of urine LH detection kits to time intrauterine insemination with donor sperm," Human Reproduction, vol. 20, no. 9, pp. 2542-2545, 2005.
[92] J. Zaidi, "Blood flow changes in the intraovarian arteries during the periovulatory period: relationship to the time of day," Ultrasound in Obstetrics and Gynecology, vol. 7, no. 2, pp. 135140, 1996.

[93] J. D. Alvarez, A. Hansen, T. Ord et al., "The circadian clock protein BMAL1 is necessary for fertility and proper testosterone production in mice," Journal of Biological Rhythms, vol. 23, no. 1, pp. 26-36, 2008.

[94] I. Campos Costa, H. Nogueira Carvalho, and L. Fernandes, "Aging, circadian rhythms and depressive disorders: a review," American Journal of Neurodegenerative Disease, vol. 2, no. 4, pp. 228-246, 2013.

[95] C. A. McClung, "Circadian rhythms and mood regulation: insights from pre-clinical models," European Neuropsychopharmacology, vol. 21, supplement 4, pp. S683-S693, 2011.

[96] W. P. Witt, T. Deleire, E. W. Hagen et al., "The prevalence and determinants of antepartum mental health problems among women in the USA: a nationally representative populationbased study," Archives of Women's Mental Health, vol. 13, no. 5, pp. 425-437, 2010.

[97] B. L. Parry, C. J. Meliska, D. L. Sorenson et al., "Plasma melatonin circadian rhythm disturbances during pregnancy and postpartum in depressed women and women with personal or family histories of depression," The American Journal of Psychiatry, vol. 165, no. 12, pp. 1551-1558, 2008.

[98] K. M. Sharkey, T. B. Pearlstein, and M. A. Carskadon, "Circadian phase shifts and mood across the perinatal period in women with a history of major depressive disorder: a preliminary communication," Journal of Affective Disorders, vol. 150, no. 3, pp. 1103-1108, 2013.

[99] B. R. Wilsmore, R. R. Grunstein, M. Fransen, M. Woodward, R. Norton, and S. Ameratunga, "Sleep habits, insomnia, and daytime sleepiness in a large and healthy community-based sample of New Zealanders," Journal of Clinical Sleep Medicine, vol. 9, no. 6, pp. 559-566, 2013.

[100] A. M. Sangoram, L. Saez, M. P. Antoch et al., "Mammalian circadian autoregulatory loop: a timeless ortholog and mPerl interact and negatively regulate CLOCK-BMAL1-induced transcription," Neuron, vol. 21, no. 5, pp. 1101-1113, 1998.

[101] T. Hunt and P. Sassone-Corsi, "Riding tandem: circadian clocks and the cell cycle," Cell, vol. 129, no. 3, pp. 461-464, 2007.

[102] Z.-L. Zeng, M.-W. Wu, J. Sun et al., "Effects of the biological clock gene Bmall on tumour growth and anti-cancer drug activity," Journal of Biochemistry, vol. 148, no. 3, pp. 319-326, 2010.

[103] S. Lee, L. A. Donehower, A. J. Herron, D. D. Moore, and L. Fu, "Disrupting circadian homeostasis of sympathetic signaling promotes tumor development in mice," PLoS ONE, vol. 5, no. 6, Article ID e10995, 2010.

[104] K. A. Dyar, S. Ciciliot, L. E. Wright et al., "Muscle insulin sensitivity and glucose metabolism are controlled by the intrinsic muscle clock," Molecular Metabolism, vol. 3, no. 1, pp. 29-41, 2014.

[105] J. Pflaum, S. Schlosser, and M. Müller, "P53 family and cellular stress responses in cancer," Frontiers in Oncology, vol. 4, article 285, 2014.

[106] X. Wang, A. Ji, Y. Zhu et al., "A meta-analysis including doseresponse relationship between night shift work and the risk of colorectal cancer," Oncotarget, vol. 6, no. 28, pp. 25046-25060, 2015.

[107] B. B. Kamdar, A. I. Tergas, F. J. Mateen, N. H. Bhayani, and J. Oh, "Night-shift work and risk of breast cancer: a systematic review 
and meta-analysis," Breast Cancer Research and Treatment, vol. 138, no. 1, pp. 291-301, 2013.

[108] U. Weissbein, N. Benvenisty, and U. Ben-David, "Quality control: genome maintenance in pluripotent stem cells," Journal of Cell Biology, vol. 204, no. 2, pp. 153-163, 2014.

[109] H. Murakami and P. Nurse, "DNA replication and damage checkpoints and meiotic cell cycle controls in the fission and budding yeasts," Biochemical Journal, vol. 349, no. 1, pp. 1-12, 2000.

[110] G. A. Bjarnason, R. C. K. Jordan, P. A. Wood et al., "Circadian expression of clock genes in human oral mucosa and skin: association with specific cell-cycle phases," The American Journal of Pathology, vol. 158, no. 5, pp. 1793-1801, 2001.

[111] Y. Wang, R. Qian, N. Sun, C. Lu, Z. Chen, and L. Hua, "Circadian gene hClock enhances proliferation and inhibits apoptosis of human colorectal carcinoma cells in vitro and in vivo," Molecular Medicine Reports, vol. 11, no. 6, pp. 4204-4210, 2015.

[112] S. K. Chun, S. Chung, H.-D. Kim et al., "A synthetic cryptochrome inhibitor induces anti-proliferative effects and increases chemosensitivity in human breast cancer cells," Biochemical and Biophysical Research Communications, vol. 467, no. 2, pp. 441-446, 2015.

[113] S. K. Chun, J. Jang, S. Chung et al., "Identification and validation of cryptochrome inhibitors that modulate the molecular circadian clock," ACS Chemical Biology, vol. 9, no. 3, pp. 703-710, 2014.

[114] PDQ Adult Treatment Editorial Board, "Adult non-Hodgkin lymphoma treatment $\left(\mathrm{PDQ}^{\circledR}\right)$ : health professional version," in $P D Q$ Cancer Information Summaries, National Cancer Institute (US), Bethesda, Md, USA, 2002. 


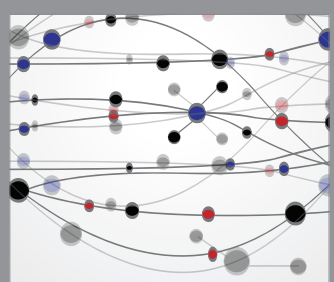

The Scientific World Journal
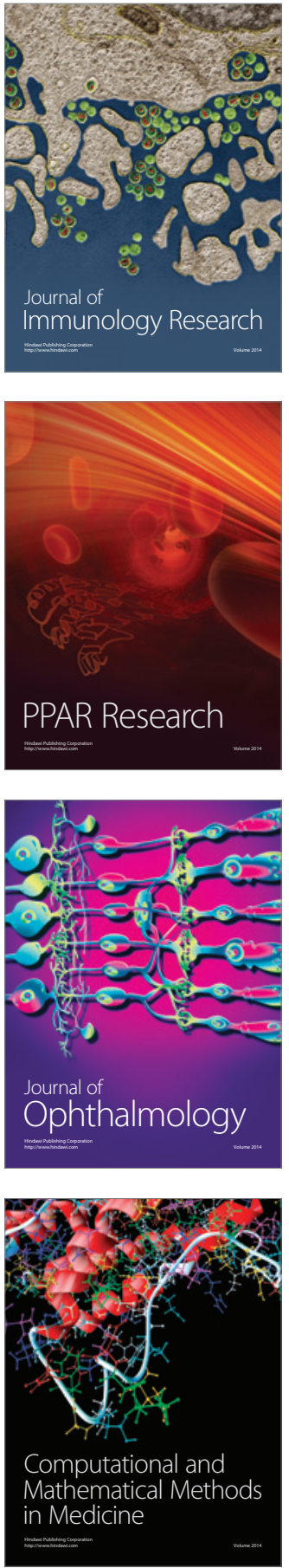

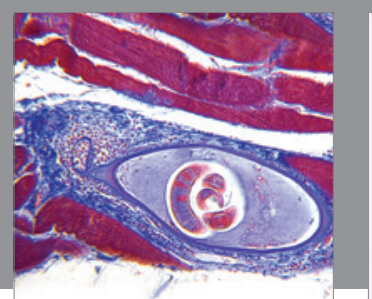

Gastroenterology Research and Practice

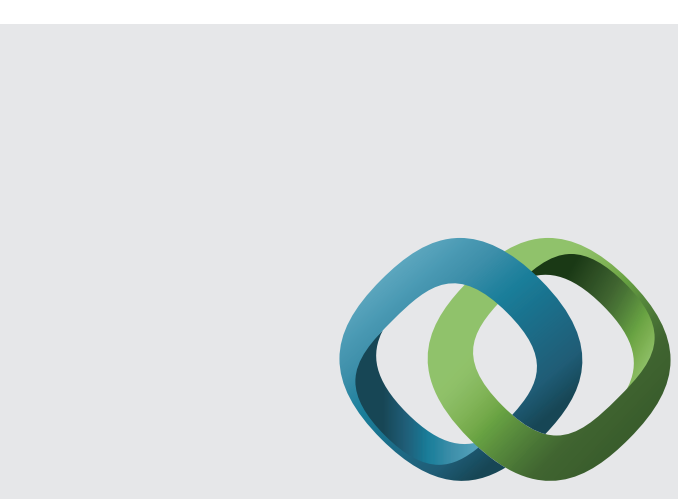

\section{Hindawi}

Submit your manuscripts at

http://www.hindawi.com
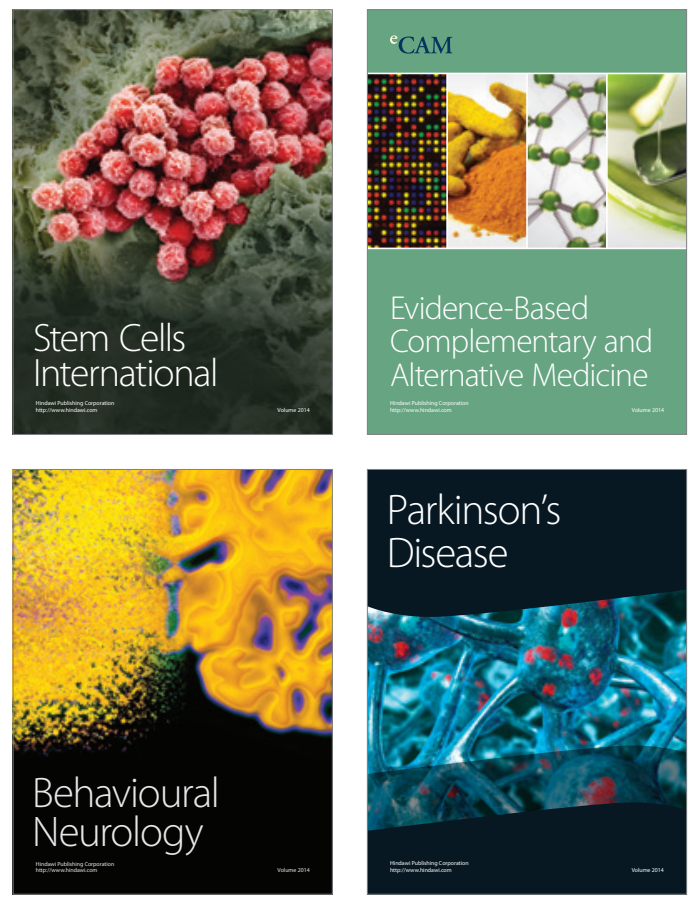
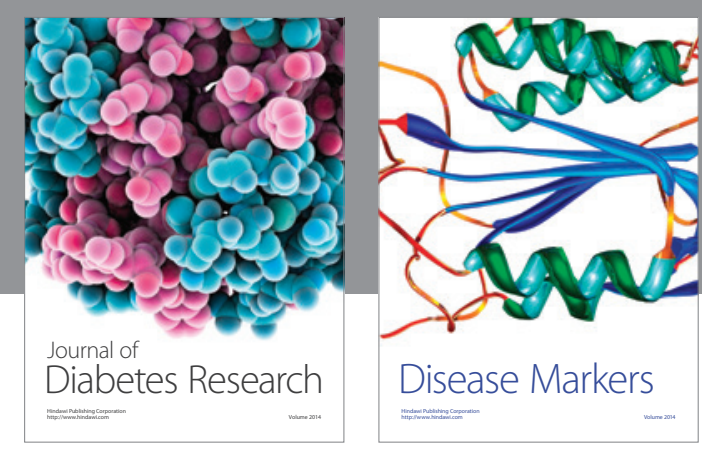

Disease Markers
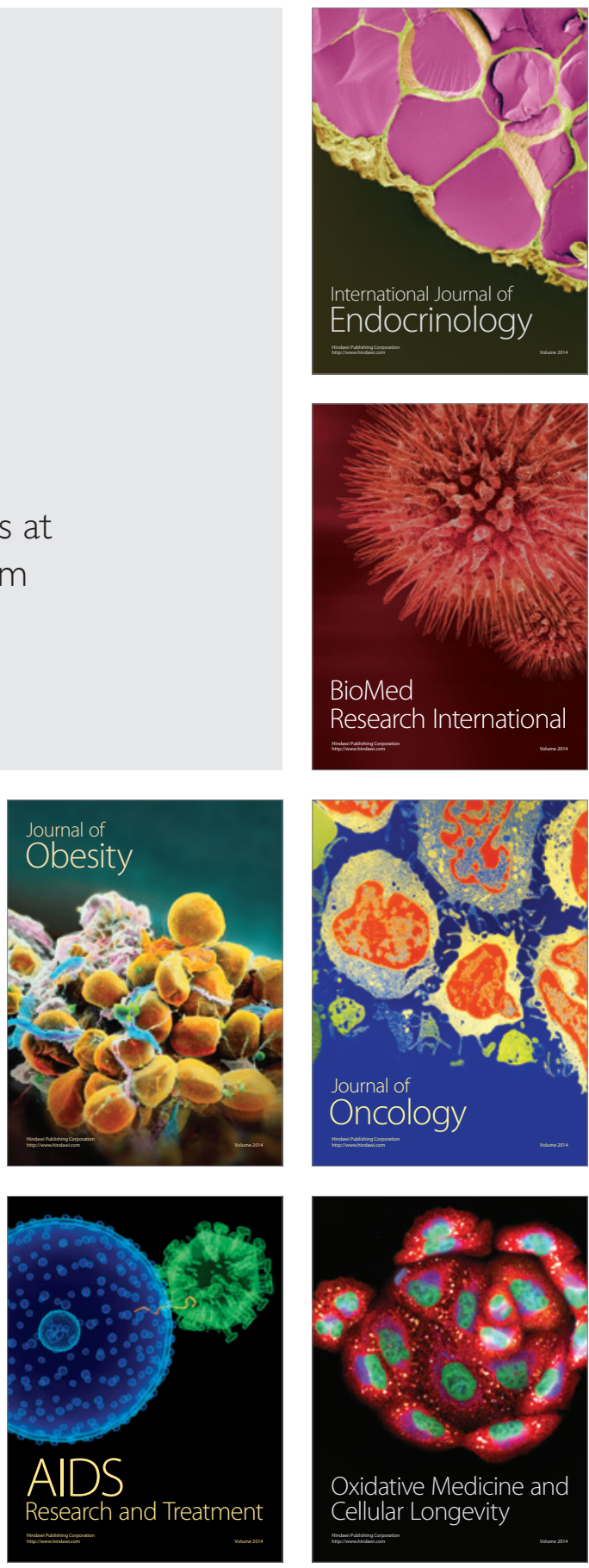